\title{
How to Explain the Transnational Security Governance of the European Union?
}

\section{Kamil Zwolski}

\begin{abstract}
This article argues that empirical developments in international security governance offer untapped opportunities for strengthening intellectual links between European Union studies and international relations. To uncover these links, the article first demonstrates how the European Union has started to address various chemical, biological, radiological and nuclear security risks through adopting an approach conceptualized as transnational security governance. The article subsequently argues that this approach can be convincingly explained by drawing on the insights from the study of the sociology of bureaucracy and bureaucratic behaviour in international relations. In this story, the European Union's approach to international security is an example of normal bureaucratic practice, stemming in particular from the bureaucracy's moral and expert authority. Importantly, the engagement with the broader social science scholarship will benefit European Union studies as much as other sub-disciplines.
\end{abstract}

Acknowledgements: An earlier version of this article was presented at the EISA $8^{\text {th }}$ PanEuropean Conference on International Relations in Warsaw (September 2013). I wish to thank Mai'a K. Davis Cross, Jonathan Havercroft, Åsne Kalland Aarstad, three anonymous reviewers and the Editors for their very helpful comments.

\section{Introduction}

The relationship between European Union (EU) studies and the broader field of international relations (IR) remains problematic and somewhat awkward. Although both fields could benefit enormously from each other's theoretical and empirical insights, they tend to be indifferent to one another. On the one hand, EU scholars often consider their subject so unique that new 
theories and frameworks have to be (re)invented each time they want to understand or explain an empirical phenomenon. On the other hand, IR scholars are often disinterested in EU studies, thus omitting empirical evidence relevant for different IR questions, such as those concerning global governance (Warleigh-Lack, 2011) or new regionalism (Warleigh, 2004; Warleigh-Lack and Rosamond, 2010). As a result, EU studies risk becoming self-referential as well as ignored by IR and broader political science (Rosamond, 2006).

This article argues that the empirical developments in the EU offer unexploited opportunities for both drawing from and enriching the scholarship on the sociology of (international) bureaucracy, global security governance and IR. Importantly, this argument has been partially inspired by two intellectual invitations in this journal. Firstly, Per M. Norheim-Martinsen (2010) has invited scholars to fully embrace 'governance' as a framework to better understand the dynamics of the EU's Common Security and Defence Policy (CSDP). The 'governance approach', as he has argued, directly challenges realist and inter-governmentalist theories about the nature of the EU's security co-operation. In contrast to Norheim-Martinsen's focus on CSDP and military co-operation, this article suggests that the EU's policy on chemical, biological, radiological and nuclear (CBRN) matters offers even more fertile ground for incorporating the governance approach. As such, this article also contributes to the debate on the theoretical foundations of the EU's international security policy, as initiated in the 2011 Special Issue of this journal entitled 'Security Cooperation beyond the Nation State: The EU's Common Security and Defence Policy'. Again, this article argues that the EU's international security apparatus beyond the CSDP framework can offer valuable insights for students of IR and international bureaucracy.

Secondly, Alex Warleigh-Lack and Ben Rosamond (2010) have called for a more explicit dialogue between the studies on European integration and 'new regionalism'. Elsewhere, Warleigh-Lack (2011) has also pointed out that although European studies can offer valuable 
insights to scholars studying the processes of global governance, it is partially the responsibility of EU scholars to initiate the exchange of ideas across intellectual borders. The aim of this article is to foster such exchange by demonstrating how the EU's transnational security governance on CBRN risk mitigation can be explained by the story which is not derived from EU studies. It has become a commonplace to explain the international behaviour of the EU through the narratives involving the concepts of 'civilian' (Duchêne, 1972) or 'normative' (Manners, 2002; Whitman, 2011a) power Europe. Although they are very different, both concepts presume that the character of the EU's external activities is somewhat unique. ${ }^{1}$ The EU studies-based explanation helps to uncover insightful patterns in the EU's external behaviour. However, it can also reinforce the $\mathrm{N}=1$ problem when studying the EU. This is why it is also helpful to explore alternative explanations, which depict the EU's international security policy as normal for an international bureaucracy. To this end, the article engages with the scholarship on the sociology of bureaucracy and bureaucratic behaviour in IR, potentially opening the room for comparative analysis with non-EU cases.

The article begins with the constitutive argument conceptualizing an important part of the EU's policy on CBRN risk mitigation as an example of the transnational security governance approach. This exercise in descriptive synthesis will shed more light on a unique case study of CBRN Risk Mitigation Centres of Excellence (CoE). The CBRN CoE is an innovative project launched by the EU in 2009, with the purpose of 'developing comprehensive tailored training and assistance packages' in the field of CBRN risk mitigation (European Commission, 2009, p. 8). These training and assistance packages are directed at the regions considered by the EU as vulnerable, currently including different parts of Africa, the Middle East,

\footnotetext{
${ }^{1}$ It must be noted that non-EU cases are increasingly explored in the context of the 'normative power' narrative. See, for example, Maull (1990); Diez, (2005); Special Issue on Normative Power Europe in Cooperation and Conflict, Vol. 48, No. 2.
} 
South East Asia and South East Europe. In terms of policy practice, the EU has established a number of Regional Secretariats, which act as focal points for coordinating national and regional project development and for establishing long-term, transnational networks of CBRN experts. The initiative is financed through the EU's Instrument for Stability (IfS).

In the second part, this article proposes an explanation of the EU's transnational security governance approach which derives from the study of domestic bureaucracy in sociology and international bureaucracy in IR. In this narrative, the EU, together with other international organizations (IOs), is considered an international bureaucracy (Barnett and Finnemore, 2004). As a bureaucracy, the EU must be expected to develop a set of practices typical for this form of organization. The third part brings together the descriptive and analytical arguments of the article by addressing the following question: what are the implications for the concept of security governance if we conceptualize IOs as international bureaucracies? By incorporating the insights from the scholarship on IR and the sociology of bureaucracy, this article offers a practical example of how intellectual bridges can be developed across social sciences borders. The benefits and possible research programmes stemming from this rapprochement are further discussed in the conclusion.

\section{The EU's transnational security governance and CBRN risk mitigation}

The constitutive argument conceptualizing the EU's CBRN CoE as an example of transnational security governance is developed in two stages. In the first stage, the article reflects on the value of 'security governance' framework in studying the EU's international security policy. In the second stage, the article incorporates the 'security governance' framework, as originally developed by Webber et al. (2004) and further operationalized by Norheim-Martinsen (2010), to introduce the key attributes of the CBRN CoE project.

\section{European security governance beyond CSDP}


Why has the 'governance' approach become so popular among scholars researching the dynamics of the EU's international security policy? As the Figure 1 demonstrates, the usage of the phrase 'security governance' in European studies journals has increased meaningfully between 2000 and 2012. The sample of journals includes JCMS: Journal of Common Market Studies, Journal of European Public Policy, Journal of European Integration and European Security.

\section{FIGURE 1}

The short answer is that the 'governance turn' in the scholarship on the EU's international security policy reflects the broader trend in the study of international security co-operation, with the growing focus on horizontal processes and non-state actors (Krahmann, 2003a; Webber et al. 2004; Kirchner, 2006; Kirchner and Sperling, 2007; Schroeder, 2011). Schroeder (2011, p. 31) neatly encapsulates the key characteristics of 'governance' as referring to 'a mode of political decision-making beyond hierarchical government of a traditional interventionist state'. This is a very broad definition, but in fact it may even be too restrictive, because governance does not have to take place only at the 'decision-making' stage. As Rosenau (1995) argues, governance may include 'systems of rule', which entail 'control' and 'steering'. Schroeder further notes that governance 'provides a framework for understanding the fragmentation of authority to new actors and levels, and it enables a comprehensive analysis of interactions in a sector characterized more by complex decision-making and nested responsibilities for action' $(2011$, p. 31). While consensus seems to have emerged that 'governance' is well suited to analyse the EU's international security policy-making, it is unclear what parts of the EU's institutional apparatus should be included in the analysis.

Following the EU's own post-Maastricht vocabulary, the second pillar, and particularly the CSDP framework, has occupied a central place in the scholarship on the EU's role in interna- 
tional security (Knodt and Princen, 2003, p. 2). For example, Norheim-Martinsen (2010), while aiming to contribute to the literature on the EU's security governance, focuses on its only one aspect, i.e. the CSDP. Although each effort to better our understanding of the EU's international security apparatus is to be valued, the EU's security governance is a term more encompassing than is often acknowledged in the literature. In its external dimension, the security governance of the EU must also include longer-term and structural elements, most notably the IfS (Gänzle, 2009; Whitman and Wolff, 2012; Zwolski, 2012a; 2012b). Consequently, although Norheim-Martinsen (2010) aimed for his analysis of the CSDP governance to challenge inter-governmentalism, we cannot truly achieve this objective without the inclusion of structural instruments, such as the IfS, in the analysis. Furthermore, as this article demonstrates, the budgetary instruments on the verge of security and development assistance make the EU's security governance genuinely transnational.

Admittedly, a truly comprehensive approach to studying the EU's international security role is challenging. Nonetheless, we cannot ignore consistent empirical developments that trespass the boundaries dividing the CSDP and the former Community pillar policies and instruments (Keukeleire and MacNaughtan, 2008; Smith, 2008; Kaunert and Zwolski, 2013). Even more importantly, we cannot ignore such developments when incorporating the 'governance' approach. As already hinted, there are different conceptualizations of security governance, including various attempts at summarising this strand of the scholarship (Kirchner and Domínguez, 2011, pp. 5-11; Sperling, 2009, pp. 4-6; Schroeder, 2011, pp. 30-36). The most common approach is to adapt the 'governance turn' in IR (Rosenau and Czempiel, 1992), European Studies (Kohler-Koch and Rittberger, 2006) or national politics (Rhodes, 1997) to the problem of security cooperation. It is impossible here to identify all the approaches to the 'security governance' concept. Instead, the article incorporates the model developed by a group of scholars (Webber et al., 2004) and revisited by Norheim-Martinsen (2010), who has identi- 
fied the EU's security governance to (a) consist of multiple centres of power, (b) include the interaction of multiple actors, (c) contain formal and informal institutionalization, (d) include ideational relations between actors and (e) involve collective purpose. All of these attributes desperately require the broadening of the scholarly focus, to also include the transnational instruments such as the IfS.

\section{Security governance and the EU's CBRN network-based approach}

The argument of this section is that the conceptual benefits of the 'security governance' approach can only be fully exploited when moving beyond the CSDP framework and the military co-operation in the EU. In fact, the CBRN non-proliferation, identified at the top of the EU's international security agenda, requires instruments and policies other than those related to the military. In this context, the CBRN CoE initiative has emerged as the flagship EU approach to CBRN risk mitigation, which is the result of two factors. Firstly, the CBRN nonproliferation was allocated with the largest proportion of the IfS budget under Article 4, defining the EU's assistance in the stable conditions for co-operation ( $€ 266$ million for the years 2007-13 = 13 per cent of the total budget) (European Commission, 2007). Secondly, in the pool available for CBRN non-proliferation, the CBRN CoE initiative is defined as the 'number one' priority area for the EU (European Commission, 2009; 2012). This is unsurprising, considering that the EU has long planned to move its assistance beyond the former Soviet Union and the CBRN CoE enabled the EU to go global. Further, in light of the criticism directed towards its previous assistance programmes (Sodupe and Benito, 1998), the EU planned to change the methodology of its assistance, by decentralising it and focusing on 'local ownership'. Moreover, CBRN CoE reflect the priorities of the United Nations Security Council Resolution 1540, which provides the international context for the EU's initiative. 
How can the concept of 'security governance' synthesize the attributes of the EU's transnational CBRN policy? The aforementioned five features of the 'security governance' concept are incorporated into the analysis. With respect to the question of heterarchy, multiple centres of power are inevitable in the system of transnational security governance, regardless of how depoliticized it may appear. Indeed, we can expect the existence of the multiple centres (and relations) of power at different levels in the case of CBRN CoE. At the EU institutional level, the Council of Ministers has been slowly growing into coordinating its policies vis-à-vis international non-proliferation regimes, such as the Review Conferences of the NonProliferation Treaty (Portela, 2004; Müller, 2005). In parallel, the European Commission has been involved in low-key non-proliferation activities in the former Soviet Union since the early 1990s (Zwolski, 2011a; 2011b). When the Commission announced its ambitions to expand the scope of its CBRN non-proliferation policy (with CBRN CoE currently being the main embodiment of this ambition), it even sparked irritation in the Council (House of Lords, 2005, p. 38). Lisbon Treaty reforms offer opportunities to bring more coherence to the CBRN policy of the EU. This does not preclude, however, that the existence of the multiple centres of power will not affect the actual implementation of $\mathrm{CBRN} \mathrm{CoE}$ at regional and national levels. Project coordinators recognize some of the challenges:

Secretariats of the Centres of Excellence will be small structures composed of ten people. They will be subject to pressure by national CBRN teams wanting to put forward national agendas. Impartiality skills and corruption awareness training (financial and technology vigilance) will be offered to progressively uncouple the regional team experts from their national origin (Dupré and Servais, 2012, p. 5).

With regards to the multiple actors dimension of security governance, CBRN CoE involve a broad variety of stakeholders at all levels. This is not surprising, because 'cooperation and coordination between all levels of government and international partners' is at the core of the 
IfS in the area of CBRN matters (European Commission, 2011, p. 6). Within the EU, the project is coordinated by the European Commission (Joint Research Centre, Development and Cooperation-EuropeAid) and the European External Action Service (EEAS), with the potentially greater role of the member states (Dupré and Servais, 2012). United Nations Interregional Crime and Justice Research Institute (UNICRI) is involved in the implementation. At the national level, the $\mathrm{CBRN} \mathrm{CoE}$ are developed and implemented through the co-operation of the so-called National Focal Points of the Partner Countries, which are countries outside the EU participating in the networks. They develop regional CBRN risk mitigation projects through the aforementioned Regional Secretariats (Mignone, 2013).

The EU's CBRN risk mitigation approach does not just include, but is defined by, formal and informal institutionalization. Informal institutionalization is at the core of CBRN CoE, with hundreds of experts and policy-makers meeting at regional workshops and preparing joint applications for CBRN risk mitigation resources (Schmidt, 2013). Projects approved for funding range from the transfer of best practice in areas such as inter-agency CBRN response, to the provision of training and mentoring on identifying chemical material at borders and the development of legislation on biosafety and biosecurity (European Union, 2013, pp. 2-4). Informal institutionalization overlaps with formal institutionalization in the networkbased system such as CBRN CoE. The already-mentioned National Focal Points of the Partner Countries can comprise a variety of actors as diverse as first responders, police, customs, CBRN agencies, ministries, academia and intelligence (Winfield, 2011, p. 50). They form teams of around 20-30 experts, representing a country at the regional level through cooperation with Regional Secretariats. Such teams may play important integrative roles, because 'in many cases it is the first time that many of the representatives that cover the whole of CBRN in a country have sat down and talked to each other' (Winfield, 2011, p. 50). 
'Security governance' also includes relations between actors that are ideational. Importantly, there already exists a significant body of scholarship concerning the role of norms in the EU's international security policy (Risse-Kappen, 1997; Whitman, 1998; Manners, 2002). It is therefore important to broaden the outlook in order to identify the ideational challenges facing the EU in its arguably innovative approach to transnational security governance. These challenges concern the fact that the co-operation with partner countries is voluntary; it involves important matters of security risks; and the countries are asked to think through the lens of regional needs, not merely national interests. This approach is fundamentally different from the traditional role of IOs facilitating interstate co-operation. It requires national leaders in the Middle East, North Africa, South East Europe, South East Asia and African Atlantic Façade to adjust their thinking about preventing CBRN risks. Leaders in these regions are implicitly asked by the EU and UNICRI to operate under the assumption that their interests in CBRN matters are not so different as to prevent them from developing joint security projects. Building local and regional trust is the intended original contribution of the EU's CBRN CoE to the environment where different nuclear research and technical centres already exist. In fact, project coordinators argue that in such a sensitive field as CBRN, trust and confidence are pivotal for improving security in a long term: 'We will not make a real difference in threat/risk reduction on the mere substance of our projects. Something has to come first: Trust and Confidence Building Measures' [original emphasis] (Dupré and Servais, 2012, p. 2).

A sense of collective purpose is the final attribute of the security governance approach. It is a result of both structure and process. From the structural perspective, purpose is the outcome of institutionalization, because institutions 'entrench particular forms of behaviour among their participants by prescribing rules of entry, norms of interaction and constraints on behaviour' (Webber et al., 2004, p. 8). There are questions about the 'sense of purpose' in the EU's 
CBRN transnational security governance, particularly after the Lisbon Treaty reshuffled the decision-making apparatus by moving the parts of the European Commission and the Council Secretariat to the newly-established EEAS. Institutional cultures have been long established in both the Commission and the Council, and it may take a while for the new culture to emerge (Whitman, 2011b). From the process perspective, governance is underpinned by policy outcomes, including how they take shape. In $\mathrm{CBRN} \mathrm{CoE}$, the outcomes will be affected by a number of factors, including the commitment of EU member states; access to relevant expertise; interaction by different project teams; the ability to establish geographical and thematic priorities; establishing an accurate verification mechanism and communicating the outcomes to a wider audience (Dupré and Servais, 2012; Mignone, 2013).

Synthesizing the attributes of the EU's CBRN risk mitigation policy under the concept of transnational security governance can, in itself, lead to interesting observations. At the same time, however, the constitutive mode of argumentation in this case provides little theoretical value for uncovering the driving factors behind the EU's approach to security governance. As a result, the synthesis on its own provides an important first step to explaining the EU's transnational security governance approach, but it subsequently must be subjected to the question 'of what is this an instance?' (Rosenau and Durfee, 1995, p. 183).

The remaining part of this article suggests that the EU's leading CBRN-related project, involving the creation of $\mathrm{CBRN} \mathrm{CoE}$, constitutes an expected outcome of normal bureaucratic politics. In order to further explore this explanation, the article must turn to sociological and IR insights concerning the nature of bureaucracy, particularly its sources of authority. Max Weber's (1978) insights on bureaucratic authority are significant in this narrative, because they help to better explain why the EU, or any other international bureaucracy, would adopt an approach to international security governance that is purely managerial, with experts and expertise at its core. Furthermore, social constructivist insights can help to better embed this 
story in the IR vocabulary by incorporating Weberian ideas about bureaucracy into how we understand modern IOs (Barnett and Finnemore, 2004).

\section{The EU as a normal bureaucracy}

The idea that IOs are bureaucracies has been put forward by social constructivist scholars Michael Barnett and Martha Finnemore (2004). They have advanced their arguments against the dominant view that IOs mostly do what states want them to do, and thus studying their autonomous intentions and behaviour is bound to be an unfruitful endeavour. If IOs are bureaucracies, then we should expect them to follow a range of impersonal rules-building blocks of bureaucracies. Barnett and Finnemore (2004) identify four effects that bureaucratic rules have on IOs. Firstly, rules prescribe actions for an organization both internally and externally. Internally, rules dictate the type of behaviour that is considered 'normal'. Externally, IOs develop new sets of rules aiming at other international actors, such as countries in conflict. Secondly, rules define how IOs perceive, organize and interpret the world. Thirdly, rules are used by IOs to create or constitute the social world; predictably the world created by IOs is typically amenable to intervention by IOs themselves. Fourthly, rules can be constitutive of the organization's identity. For example, the UN emphasizes the importance of consent in its approach to conflict resolution.

The sole fact that IOs are bureaucracies, however, offers an incomplete explanation of the transnational security governance approach of the EU. To acquire a more insightful picture, we must ask about the sources of the IO's authority to undertake action at the international level. The scholarship on the legitimacy of organizations, including international bureaucracies, is heavily indebted to Max Weber (1978) who distinguished among charismatic, traditional and legal (rational) authority. In particular, the third ideal type of authority has been subsequently incorporated into the study of organizations. In this context, Richard Scott 
(2008) has identified two distinctive approaches. The first approach accentuated the relationship between legitimacy and the goals of organizations, asking whether these goals are congruent with social norms and values (Parsons, 1960; Pfeffer and Salancik, 1978). The second approach, in contrast, has focused on the organizations' structures and procedures (Meyer and Rowan, 1977). The argument here is that 'organizational success depends on factors other than efficient coordination and control of productive activities' (Meyer and Rowan, 1977, p. 352). Instead, the prospects for the survival of organizations is directly related to their highly elaborated institutional environments and how isomorphic with these environments organizations become (Meyer and Rowan, 1977). As the rest of this article demonstrates, these organizational structures and procedures offer valuable insights into explaining the EU's particular approach to international security policy.

\section{The moral authority of international bureaucracies}

Applying Weberian arguments about legitimacy to IR, Barnett and Finnemore (2004) have identified three sources of the IOs' authority: delegated authority, moral authority and expert authority. While the first source is important, because it refers to the authority delegated to IOs by states, it is the other two sources that can shed most light on the practices of the EU in international security governance. In particular, the case of $\mathrm{CBRN} \mathrm{CoE}$, as an intended impartial network of experts in CBRN matters very broadly construed, requires strong authority to secure the commitment of regions and countries as diverging as Jordan, Morocco, Ukraine and Singapore. This challenge seems to be recognized by EU project coordinators, who emphasize the importance of trust and confidence building (Dupré and Servais, 2012, p. 2), local resources and expertise (Winfield, 2011, p. 48) and the voluntary character of CBRN networks (Van der Meer, 2013, p. 3). 
Moral authority refers to the intended neutral, impartial and even depoliticized behaviour of IOs vis-à-vis self-interested states. How do IOs develop moral authority? As Meyer and Rowan (1977) argue, organizations gain legitimacy, resources and stability through adhering to certain myths. These myths are simply institutional rules that lead to the formalization of organizational structures. The myths have two attributes. Firstly, they 'identify different social purposes as technical ones and specify in a rule-like way the appropriate means to pursue these technical purposes rationally' (Meyer and Rowan, 1977, pp. 343-44). Arguably, building on the fact that bureaucracies draw their authority from their very nature of being impersonal, they are subsequently in a better position than states to frame even the most sensitive national security problems in more neutral, depoliticized terms. When security problems are framed by international bureaucracies, mostly in technical rather than political terms, IOs can more credibly position themselves as legitimate authorities possessing, or capable of organizing, necessary resources to address such problems.

Secondly, the myths enabling the formalization of organizations are highly institutionalized, and thus 'beyond the discretion of any individual participant or organization' (Meyer and Rowan, 1977, p. 344). For example, the myth of 'expert knowledge' is highly institutionalized by the established Western educational system. This myth is very important as a source of the IOs' authority and thus it requires treatment in a separate, following section. Here, it is primarily mentioned for its property of making political problems seem less contentious and more neutral (Eriksen, 2011). Similarly, the myth of 'transnational policy networks' as a desirable form of governance is highly institutionalized by the 'governance turn' in international co-operation, enabling non-hierarchical structures and multiple actors (Krahmann, 2003b). Such underlying myths contribute to the legitimacy of international bureaucracies and shape the way in which their practices become formalized. In the case of the EU's transnational security governance, the ambition to frame problems as technical in nature is further amplified 
by the sensitivities associated with security policy. The myths or institutional rules concerning 'expert knowledge', 'transnational networks' or 'international prestige' all work to the IOs' advantage in the process of formalizing policy structures such as CBRN CoE.

\section{The expert authority of international bureaucracies}

In addition to the delegated and moral authority of IOs, Barnett and Finnemore (2004) also distinguish expert authority. Max Weber has observed that, essentially, bureaucracy is 'domination through knowledge' (1978, p. 225), which consists of technical knowledge - itself an important source of power, but also of knowledge stemming from experience in service. Writing his contribution over 90 years ago, Weber $(1978$, p. 975) has already noted that ' $[\mathrm{t}] \mathrm{he}$ more complicated and specialized modern culture becomes, the more its external supporting apparatus demands the personally detached and strictly objective expert'. Weber was writing about the growing complexity of culture long before the digital age revolutionized the sources and nature of security risks, introducing new levels of complexity and technological progress (Giddens, 1990; Beck, 1999). In consequence, we require experts to address these risks at least as much as states needed tanks to conduct warfare in the $20^{\text {th }}$ century.

The reliance on different kinds of expertise provides IOs with a significant source of authority. It is also an important basis of their power due to the growing gap between experts and those who depend on experts' knowledge and experience (Scott, 2001, p. 108). Nowhere is this need for expertise as apparent as in the field of CBRN security, involving a myriad of technical and political challenges. CBRN CoE, as a form of transnational security governance, aims to fill the need for expertise at national and regional levels. Among the key objectives of the initiative are (a) to provide CBRN training to participating countries; (b) to support participating countries in developing legal, administrative, and technical measures; and (c) to provide a coherent package of training and assistance covering CBRN matters such as 
export control, illicit trafficking, crisis response and redirection of scientists (European Commission, 2009). At the same time, however, the highly specialized expertise required puts a strain on the availability of human resources in the EU and in participating countries (Mignone, 2013, p. 7). Furthermore, with 29 projects implemented by 18 entities in 42 different countries, as was the case in mid-2013 (Schmidt, 2013, p. 1), there is a risk that the expertise which is available will not be optimally utilized (Mignone, 2013, p. 7).

Notwithstanding their access to and ability to mobilize external technical expertise, bureaucracies also appear legitimate because they typically have a long time to develop their practices (Weber, 1978). This experience-based expertise is particularly important in comparison to democratic states, where officials often have to step down when, after four or five years, they have just achieved fluency in their area of competence. We can find this (often tacit) experience-based expertise in every formal organization. We can also find it in the EU in the field of preventing CBRN-related threats. Already at the beginning of the 1990s, the European Community initiated technical assistance- - known as the Technical Aid to the Commonwealth of Independent States (TACIS) — with the security and safety of nuclear installations constituting an important component of this assistance. The low profile of the Community's activities channelled through TACIS allowed the European Commission to develop its assistance relatively uncontested, apart from the criticism directed at the actual effectiveness of TACIS (Sodupe and Benito, 1998). When, in 2009, the European Commission first outlined the rationale for CBRN CoE, it was building on its experience of managing TACIS: 'Taking into account the lessons learned through the TACIS programme and the first IfS IP [Indicative Programme], the IP 2009-2011 intends to move away from an "ad hoc", centralized approach to promoting coherent, integrated regional networks' (European Commission, 2009, p. 7). The long experience of the European Commission's Join Research Centre with CBRN 
matters, according to Heyes (2012), makes it a 'centre of excellence' even if the actual CBRN CoE have not existed long enough to label them 'excellent'.

\section{FIGURE 2}

To sum up, as Figure 3 encapsulates, the above analysis has indicated the relevance of this IR-derived story in explaining the EU's approach to international security governance. In this narrative, the EU does not have to be unique as compared to other international actors, in order to develop transnational security governance structures. Instead, the transnational security governance approach of the EU stems naturally from its character as a bureaucracy. IOs legitimize their international activities through the apparent neutrality of their expertise and impersonal rules guiding their behaviour. Consequently, it is more difficult for the governments participating in CBRN CoE to resist this co-operation on the grounds that the EU serves particularistic interests of a given state or individual. Equally, the transnational security governance approach of the EU results from its technical and experience-based expertise, as well as a long-term outlook. Importantly, the EU by itself, like other international bureaucracies, does not possess sufficient expertise to fully address complex security risks. It has learned, however, through many years of experience, to draw necessary resources from the outside. The ability of international bureaucracies to pool outside expertise in the service of their own objectives gives them enormous leverage over states which typically have more constrained resources and a shorter-term focus.

\section{International bureaucracy and security governance}

The previous sections have reinforced the scholarly argument that the international security policy of the EU can be conceptualized as a system of security governance. Further, they have suggested that the transnational security governance of the EU in the area of CBRN risk mitigation can be depicted as predictable for an international bureaucracy, because bureau- 
cracies draw their authority from their intended neutral character and expertise. The broader question that still needs addressing, however, is what the implications for the concept of security governance are if we conceptualize IOs as international bureaucracies.

No one has influenced our conception of modern bureaucracy more than Max Weber. At the same time, however, the Weberian model of a unitary state with its effective bureaucracy appears incongruent with how governance is defined in the literature. The German sociologist is rarely referenced in the governance scholarship. When references are made, they mostly serve the purpose of reinforcing the dichotomy between the Weberian ideas of hierarchy and unity on the one hand, and heterarchy and fragmentation characterizing governance systems on the other hand (Pierre and Peters, 2000, p. 81; Sellers, 2011, p. 127). This tendency is unsurprising when we consider the nation-state as the starting level of analysis, and only then we try to assess how decentralized, or how fragmented, the regional or global governance system has become. Zürn (2013, pp. 416-17) talks in this context about methodological nationalism. Enroth $(2011$, p. 31) concludes that even as governance-oriented approach as network theory 'is confined to its nation-state origins'.

The alternative route, and the one taken in this article, is to start the analysis at the level of IOs (Martin and Simmons, 2013). When an IO, and not just states, is conceptualized as a bureaucracy, we can consider it a 'distinctive social form of authority with its own internal logic and behavioural proclivities' (Barnett and Finnemore, 2004, p. 3). As a result, we can more easily identify a growing number and scope of clusters of institutions, which lead to the creation of transnational networks. Such networks can include both formal and informal organizations. Importantly, networks of international institutions also mean networks of memberships in IOs, which can 'magnify the possibilities for cooperation and expanded joint gains among members' (Martin and Simmons, 2013, p. 341). 
While the question of how fragmented and decentralized nation-states have become divides scholars of governance, IOs as bureaucracies are defined by formal and informal networks, as well as different degree of institutionalization. What becomes particularly interesting for scholars of security governance is, however, when IOs develop networks strategically, in order to achieve their policy objectives. The concept of security governance, as defined by Webber et al. (2004) and adopted by Norheim-Martinsen (2010), seems to fit particularly well to better our understanding of the system in which IOs develop such networks. This does not mean, however, that there are no tensions between various attributes of the governance system and some of the components of the IOs' authority.

The principle of heterarchy, which entails the existence of the multiple centres of power, has challenged the hierarchical notion of centralized nation-states. When the state is taken as a basic unit of analysis, heterarchy helps to account for the influence of non-state actors at different levels, in order to obtain a more accurate image of collective self-organization. Heterarchy becomes more problematic, however, in the governance system with international bureaucracies and their clusters at the centre of analysis. Here, we have to recognize the intention of IOs to present their action as depoliticized, which contrasts with the very political nature of intra- and inter-institutional relations. This tension becomes particularly apparent in security matters and has been recognized in the case of CBRN CoE, where multiple centres of power are evident.

The other attributes of the governance approach, as discussed in this article, are less contentious and better suited to understand the self-organizing, transnational system with international bureaucracies as the primary unit of analysis. While the principle of 'multiple actors' is important for the understanding of security governance which recognizes states as the basic units (Krahmann, 2003a; Weber et al. 2004), it is definitional for the transnational networks of IOs. It includes actors at all levels, with experts becoming especially prominent in the 
fields such as CBRN. The same observation concerns formal and informal institutionalization; IOs are formal institutions which constantly create other formal and informal institutions, such as discussed in this article CBRN CoE.

The remaining two attributes concern norms underpinning governance system and the nature of the collective purpose. Non-materialist accounts of security governance stress the importance of norms and ideas underpinning international co-operation (Katzenstein, 1996). Equally, norms are crucial for transnational governance systems. As the case of the CBRN CoE demonstrates, international bureaucracies may even recognize that certain norms, such as trust and confidence, are central for achieving policy objectives. Finally, both state-centric and transnational approaches to security governance must recognize the contested nature of 'purposefulness', conceptualized as the outcome of structure and process. Inevitably, selforganizing governance structures involving multiple centres of power and many different actors will struggle when a common decision or action must be taken. International bureaucracies may have the advantage, however, with their experience-based authority and intrainstitutional tacit knowledge.

\section{Conclusion, research programme and benefits to European studies}

This article has suggested one possible avenue to foster intellectual exchange across the academic boundaries of EU studies and IR. It has started with the argument of a constitutive nature, conceptualizing the EU's policy on CBRN risk mitigation as transnational security governance. In contrast to most studies theorizing and conceptualizing the EU's international security policy, this article has demonstrated that noteworthy empirical developments take place beyond the military-focused CSDP. In particular, the article has identified the CBRN CoE project as an example of the transnational security governance approach, primarily be- 
cause of its reliance on networks and experts. Following on from this constitutive argument, the article has presented a story explaining the development of the CBRN CoE by the EU.

This story, however, is not embedded in EU studies and does not depict the EU as a unique international actor. Instead, the article has argued that the EU can be conceptualized as a normal bureaucracy. In this narrative, derived from IR and the sociology of bureaucracy, IOs are conceptualized as international bureaucracies. They draw authority from their rational legal character and expertise, and not only from the act of delegation by states. Consequently, all IOs intend to act impartially and apolitically, drawing on a wide range of expertise. This explanation has proved feasible in explaining the EU's transnational security governance approach in the form of CBRN CoE. Moreover, it bears the benefit of potentially opening the door for comparative analysis, which is the first proposition concerning future research programme.

The door for comparative analysis, when the study of the EU's transnational security governance is involved, is opened potentially, because we may initially not know whether nonEU case studies exist. As Rosamond (2006) argues, however, this is not a problem, when we relax the assumption about the EU as a benchmark case. In the area of transnational security governance, treating the EU as a normal bureaucracy contributes to such relaxation, by suggesting that its approach to international security policy is potentially no different from that of other IOs. The broader community of IR scholars may find such move helpful in order to incorporate insights from European studies to compare the EU's approach to security with other confirmed or potential cases of a similar approach in other parts of the world. Potential case studies may include, for example, the initiatives developed under the auspices of (International Nuclear Security Education Network), or coordinated by (International Network for Nuclear Security Training and Support Centres), the International Atomic Energy Agency (IAEA, 2012). 
The EU's approach to transnational security governance may also offer valuable insights for the recent strand of IR scholarship concerning international practices (Adler and Pouliot, 2011). The inductive focus on international practices, defined as competent performances, promises to 'broaden the ontology of world politics, serves as a focal point around which IR theory can be structured, and can be used as a unit of analysis' (Adler and Pouliot, 2011, p. 1). The transnational security governance approach of the EU meets the basic attributes of international practices, including its patterned character, its embeddedness in a particular organizational context, and its social development through learning and training. Taking into account the growing body of research on the EU's security governance (see Figure 1), European studies have potential to offer fundamental empirical contributions to the programme of international practices research, which itself aims at building bridges across different traditions in IR.

Finally, it must be stressed that, rather than being weakened, EU studies would benefit substantially from engaging more directly with the broader discipline of IR on a more regular basis (Warleigh, 2004; Warleigh-Lack, 2011). As this article has suggested, transnational security governance of the EU offers substantial opportunities for this engagement, encouraging EU studies to actively shape IR debates concerning, for example, international bureaucracy and global security governance. At the same time, academic bridge-building would also encourage researchers to seek and explore empirical cases beyond Europe, further improving our understanding of what we can observe in the EU. All these benefits would contribute, in turn, to refining the theories and approaches derived from EU studies, such as these concerning the civilian or normative character of the EU's power.

\section{References}


Adler, E. and Pouliot, V. (2011) 'International Practices'. International Theory, Vol. 3, No. 1, pp. 1-36.

Barnett, M. and Finnemore, M. (2004) Rules for the World: International Organizations in Global Politics (Ithaca: Cornell University Press).

Beck, U. (1999) World Risk Society (Cambridge: Polity).

Diez, T. (2005) 'Constructing the Self and Changing Others: Reconsidering "Normative Power Europe"”. Millennium-Journal of International Studies, Vol. 33, No. 3, pp. 613-36.

Duchêne, F. (1972) ‘Europe’s Role in World Peace.’ In Mayne, R. (ed.) Europe Tomorrow: Sixteen European Looks Ahead (London: Fontana), pp. 32-47.

Dupré, B. and Servais, P. (2012) 'The EU CBRN Risk Mitigation Centres of Excellence'. CBRN CoE Newsletter, No. 4, October.

Enroth, H. (2011) 'Policy Network Theory.' In Bevir, M. (ed.) The SAGE Handbook of Governance (London: SAGE), pp. 19-35.

Eriksen, E.O. (2011) 'Governance Between Expertise and Democracy: The Case of European Security'. Journal of European Public Policy, Vol. 18, No. 8, pp. 1169-89.

European Commission (2007) 'The Instrument for Stability: Strategy Paper 2007-2011' (Brussels: European Commission).

European Commission (2009) 'The Instrument for Stability - Multi-annual Indicative Programme 2009-2011'. C(2009) 2641, 8 April.

European Commission (2011) Long-term responses to global security threats: Contributing to security capacity building in third countries through the Instrument for Stability (Brussels: European Commission). 
European Commission (2012) 'Multi-annual Indicative Programme 2012-2013 for assistance in the context of stable conditions for cooperation under the Instrument for Stability', C(2012) 5584 final, 20 August.

European Union (2013) 'CoE Projects Launched in January’. CBRN CoE Newsletter, No. 5, February.

Gänzle, S. (2009) Coping with the 'Security-Development Nexus': The European Community's Instrument for Stability—Rationale and Potential (Bonn: German Development Institute).

Giddens, A. (1990) The Consequences of Modernity (Cambridge: Polity in association with Blackwell).

Heyes, A. (2012) 'An Assessment of the Nuclear Security Centres of Excellence'. The Stanley Foundation, May.

House of Lords (2005) 'Preventing Proliferation of Weapons of Mass Destruction: The EU Contribution'. House of Lords Paper 96, 13th Report of Session 2004-2005 (London: Stationery Office Limited).

IAEA (2012) 'Nuclear Security Report 2012'. International Atomic Energy Agency, GOV/2012/41-GC(56)/15, 31 July.

Katzenstein, P. (ed.) (1996) The Culture of National Security: Norms and Identity in World Politics (New York: Columbia University Press).

Kaunert, C. and Zwolski, K. (2013) The EU as a Global Security Actor: A Comprehensive Analysis Beyond CFSP and JHA (Basingstoke: Palgrave). 
Keukeleire, S. and MacNaughtan, J. (2008) The Foreign Policy of the European Union (Basingstoke: Palgrave).

Kirchner, E. (2006) 'The Challenge of European Union Security Governance'. JCMS: Journal of Common Market Studies, Vol. 44, No. 5, pp. 947-68.

Kirchner, E. and Domínguez, R. (2011) 'Regional Organizations and Security Governance.' In Kirchner, E. and Domínguez, R. (eds) The Security Governance of Regional Organizations (Abingdon: Routledge), pp. 1-22.

Kirchner, E. and Sperling, J. (2007) EU Security Governance (Manchester: Manchester University Press).

Knodt, M. and Princen, S. (2003) 'Introduction: Puzzles and Prospects in Theorizing EU's External Relations.' In Knodt, M. and Princen, S. (eds) Understanding the European Union's External Relations (Abingdon: Routledge), pp. 1-16.

Kohler-Koch, B. and Rittberger, B. (2006) 'Review Article: The "Governance Turn” in EU Studies'. JCMS: Journal of Common Market Studies, Vol. 44, No. S1, pp. 27-49.

Krahmann, E. (2003a) 'Conceptualizing Security Governance'. Cooperation and Conflict, Vol. 38, No. 1, pp. 5-26.

Krahmann, E. (2003b) 'National, Regional and Global Governance: One Phenomenon or Many?'. Global Governance, Vol. 9, No. 3, pp. 323-46.

Manners, I. (2002) ‘Normative Power Europe: A Contradiction in Terms?'. JCMS: Journal of Common Market Studies, Vol. 40, No. 2, pp. 235-58. 
Martin, L.L. and Simmons, B.A. (2013) 'International Organizations and Institutions.' In Carlsnaes, W., Risse, T. and Simmons, B.A. (eds) Handbook of International Relations (London: SAGE), pp. 326-51.

Maull, H.W. (1990) 'Germany and Japan: The New Civilian Powers'. Foreign Affairs, Vol. 69, No. 5, pp. 91-106.

Meyer, J.W. and Rowan, B. (1977) 'Institutionalized Organizations: Formal Structure as Myth and Ceremony'. American Journal of Sociology, Vol. 83, No. 2, pp. 340-63.

Mignone, A. (2013) ‘The European Union's Chemical, Biological, Radiological and Nuclear Centres of Excellence Initiative'. Non-Proliferation Papers, No. 28, June.

Müller, H. (2005) The 2005 NPT Review Conference: Reasons and Consequences of Failure and Options for Repair (Stockholm: The Secretariat of the Weapons of Mass Destruction Commission).

Norheim-Martinsen, P.M. (2010) 'Beyond Intergovernmentalism: European Security and Defence Policy and the Governance Approach'. JCMS: Journal of Common Market Studies, Vol. 48, No. 5, pp. 1351-65.

Parsons, T. (1960) Structure and Process in Modern Societies (London: Collier Macmillan).

Pfeffer, J. and Salancik, G.R. (1978) The External Control of Organizations: A Resource Dependence Perspective (Hagerstown: Harper \&Row).

Pierre, J. and Peters, B.G. (2000) Governance, Politics and the State (Basingstoke: Palgrave). Portela, C. (2004) 'The EU and the NPT: Testing the New European Nonproliferation Strategy’. Disarmament Diplomacy, No.78, July/August.

Rhodes, R.A.W. (1997) Understanding Governance (Buckingham: Open University Press). 
Risse-Kappen, T. (1997) Cooperation Among Democracies: The European Influence on US Foreign Policy (Princeton: Princeton University Press).

Rosamond, B. (2006) 'The Future of European Studies: Integration Theory, EU Studies and Social Science.' In Eilstrup-Sangiovanni, M. (ed.) Debates on European Integration (Basingstoke: Palgrave), pp. 448-60.

Rosenau, J.N. (1995) 'Governance in the Twenty-first Century'. Global Governance, Vol. 1, No. 1, pp. 13-43.

Rosenau, J.N. and Czempiel, E.O. (eds) (1992) Governance without Government: Order and Change in World Politics (Cambridge: Cambridge University Press).

Rosenau, J.N. and Durfee, M. (1995) Thinking Theory Thoroughly: Coherent Approaches to an Incoherent World (Boulder: Westview Press).

Schmidt, K. (2013) 'Introduction'. CBRN CoE Newsletter, No. 6, June.

Schroeder, U.C. (2011) The Organization of European Security Governance: Internal and External Security in Transition (Abingdon: Routledge).

Scott, J. (2001) Power (Cambridge: Polity Press).

Scott, W.R. (2008) Institutions and Organizations: Ideas and Interests (London: SAGE).

Sellers, J.M. (2011) ‘State-Society Relations.' In Bevir, M. (ed.) The SAGE Handbook of Governance (London: SAGE), pp. 51-64.

Smith, K. (2008) European Union Foreign Policy in a Changing World (Malden: Polity). 
Sodupe, K. and Benito, E. (1998) 'The Evolution of the European Union's TACIS Programme, 1991-96'. Journal of Communist Studies and Transition Politics, Vol. 14, No. 4, pp. $51-68$.

Sperling, J.A. (2009) 'Introduction: Security Governance in a Westphalian World.' In Wagnsson, C., Sperling, J.A. and Hallenberg, J. (eds) European Security Governance: The European Union in a Westphalian World (Abingdon: Routledge), pp. 1-15.

Van der Meer, A. (2013) 'Interview with the new Head of Unit DEVCO B5'. CBRN CoE Newsletter, No. 6, June.

Warleigh, A. (2004) 'In Defence of Intra-disciplinarity: "European Studies", the "New Regionalism", and the Issue of Democratisation'. Cambridge Review of International Affairs, Vol. 17, No. 2, pp. 301-18.

Warleigh-Lack, A. (2011) 'Obsolete if Obstinante? Transforming European Union Studies in the Transnational Era.' In Wunderlich, J-U. and Bailey, D.J. (eds) The European Union and Global Governance (Abingdon: Routledge), pp. 13-18.

Warleigh-Lack, A. and Rosamond, B. (2010) ‘Across the EU Studies-New Regionalism Frontier: Invitation to a Dialogue'. JCMS: Journal of Common Market Studies, Vol. 48, No. 4, pp. 993-1013.

Webber, M., Croft, S., Howorth, J., Terriff, T. and Krahmann, E. (2004) 'The Governance of European Security'. Review of International Studies, Vol. 30, No. 1, pp. 3-26.

Weber, M. (1978) Economy and Society (Berkley: University of California).

Whitman, R.G. (1998) From Civilian Power to Superpower? The International Identity of the European Union (Basingstoke: Palgrave). 
Whitman, R.G. (ed.) (2011a) Normative Power Europe: Empirical and Theoretical Perspectives (Basingstoke: Palgrave).

Whitman, R.G. (2011b) 'The Rise of the European External Action Service: Putting the Strategy into EU Diplomacy?'. Available at <<http://www.euce.org/eusa/2011/papers/81_whitman.pdf >>.

Whitman, R.G. and Wolff, S. (eds) (2012) The European Union as a Global Conflict Manager (Abingdon: Routledge).

Winfield, G. (2011) ‘The Network of Excellence'. CBRNe World, Spring, pp. 47-52.

Zürn, M. (2013) ‘Globalization and Global Governance.' In Carlsnaes, W., Risse, T. and Simmons, B.A. (eds) Handbook of International Relations (London: SAGE), pp. 401-25.

Zwolski, K. (2011a) 'The External Dimension of the EU's Non-proliferation Policy: Overcoming Inter-institutional Competition'. European Foreign Affairs Review, Vol. 16, No. 3, pp. 325-40.

Zwolski, K. (2011b) 'Unrecognised and Unwelcome? The Role of the EU in Preventing the Proliferation of CBRN Weapons, Materials and Knowledge'. Perspectives on European Politics and Society, Vol. 12, No. 4, pp. 477-92.

Zwolski, K. (2012a) 'The EU and a Holistic Security Approach After Lisbon: Competing Norms and the Power of the Dominant Discourse'. Journal of European Public Policy, Vol. 19, No. 7, pp. 988-1005.

Zwolski, K. (2012b) 'The EU as an International Security Actor After Lisbon: Finally a Green Light for a Holistic Approach?'. Cooperation and Conflict, Vol. 47, No. 3, pp. 68-87. 
Figure 1: 'Security Governance' in European Studies Journals

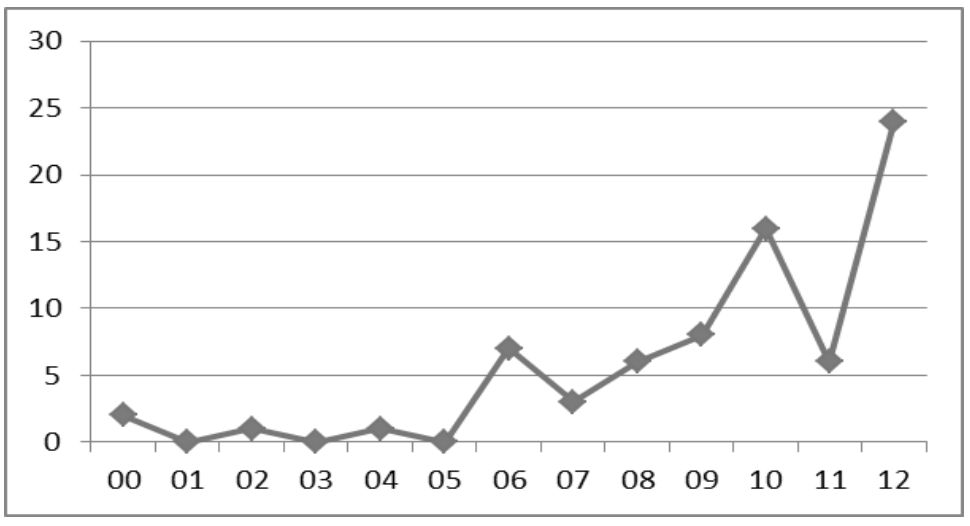

Figure 2: The EU as an International Bureaucracy

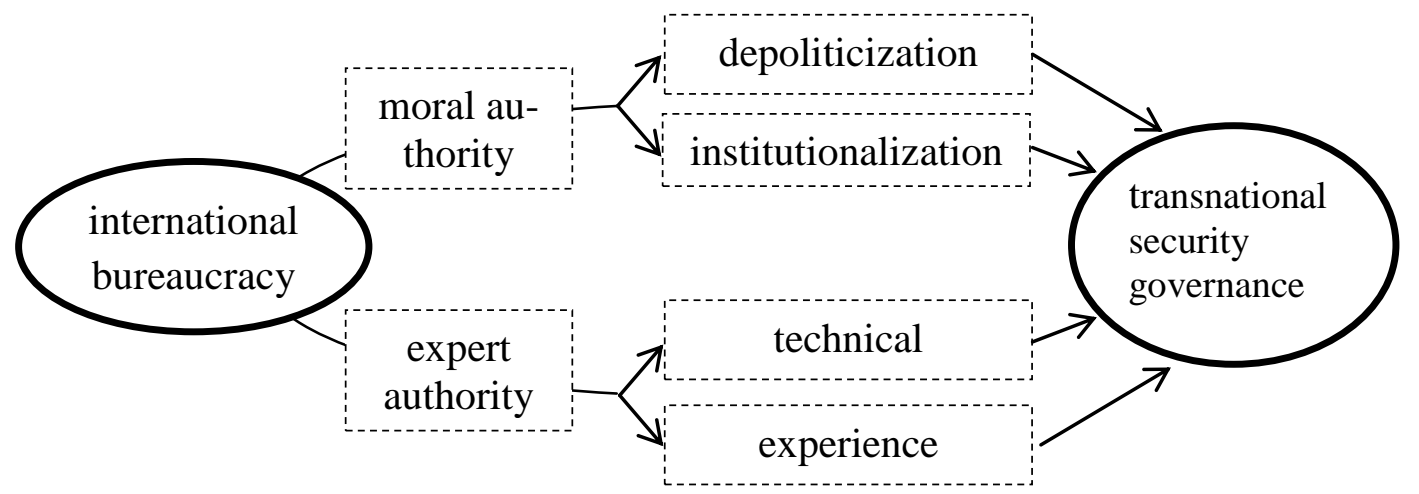

